"The nature of credit risk information disclosed in the risk and capital reports of the top-5 South African banks"

\begin{tabular}{|c|c|c|}
\hline AUTHORS & Tankiso Moloi & \\
\hline ARTICLE INFO & $\begin{array}{l}\text { Tankiso Moloi (2016). The natur } \\
\text { and capital reports of the top-5 } \mathrm{S} \\
11(3), 87-93 \text {. doi: } 10.21511 / \mathrm{bbs} \text {. }\end{array}$ & $\begin{array}{l}\text { rmation disclosed in the risk } \\
\text { Banks and Bank Systems, }\end{array}$ \\
\hline DOI & http://dx.doi.org/10.21511/bbs.1 & \\
\hline RELEASED ON & Wednesday, 12 October 2016 & \\
\hline JOURNAL & "Banks and Bank Systems" & \\
\hline FOUNDER & LLC "Consulting Publishing Cor & erspectives" \\
\hline & & $\begin{array}{l}\text { Ẽ } \\
\text { =E: }\end{array}$ \\
\hline NUMBER OF REFERENCES & NUMBER OF FIGURES & NUMBER OF TABLES \\
\hline 0 & 0 & 0 \\
\hline
\end{tabular}

C The author(s) 2023. This publication is an open access article. 


\title{
The nature of credit risk information disclosed in the risk and capital reports of the top-5 South African banks
}

\begin{abstract}
This paper used the Credit Risk Disclosure Measurement Tool (CRDMT) constructed on the basis of six main areas, namely, banks own description of credit risk (i.e., as it applies to the banks operations), banks strategy of reducing credit risk exposure (i.e., objectives of credit management), banks approach to credit modelling or the internal rating system, banks approach and the manner in which they assess their exposure to credit risk, banks credit risk mitigation strategies employed (i.e., collateral and other credit enhancements), and banks approach to the valuation of pledged collateral and other credit enhancements to assess the information disclosed on the risk and capital management reports of the top-5 South African banks.

Results demonstrated that the top-5 South African banks were fairly in line with the main six credit risk areas that would result in an informative risk and capital management report, as proposed by the CRMDT. It was observed that there were, however, pockets of information that could be improved to enhance these risk and capital management reports, particularly the credit risk information made available to public. These areas included the information relating to banks credit risk mitigation strategies employed and banks strategy of reducing credit risk exposure, as well as the information relating to banks approach to the valuation of pledged collateral and other credit enhancements. These areas were noted for their partial or non-disclosure of information.
\end{abstract}

Keywords: banks, credit risk, Credit Risk Disclosure Measurement Tool (CRDMT), disclosure analysis and risk and capital reports.

JEL Classification: G21, G32.

\section{Introduction}

In studying the role of banks, it is apparent that several researchers accept that banks are special institutions that utilize the economies of scale in the management of investments, risk reduction through diversification and the ability of banks to rely upon the law of large numbers when managing liquidity (Allen \& Carletti, 2008; Bangura, 2005; Boot \& Marinc, 2008; Diamond \& Dybvig, 1983; Gurley \& Shaw, 1960; Kaufman, 1988; Lewis, 1992; Liu, 2004 \& Wilson et al., 2010).

In this regard, it could be stated that the role of banks is that of being deposit holders. As a result of this role, banks transform themselves from being the custodian of savings (deposits) and through capital markets, they, then, transfer savings that are in their custody into investment through loans and other activities, thus, boosting the consumption functions of the economy. It is through this transformational process that Okeahalam (1998) views banks as a lubricant of the economy.

Diamond and Rajan (1998) concur with the transformational role description given above. They precisely state that in their role as a lubricant of the economy, banks transform short term liquid investments such as deposits into long term illiquid assets such as loans.

(C) Tankiso Moloi, 2016.

Tankiso Moloi, Ph.D., Professor, Department of Accountancy, University of Johannesburg, South Africa.
According to Liu (2004), banks assume several lubrication roles in the economy. Accordingly, banks lubricate the financial system by assuming the following roles:

- the repository of liquidity,

- the core payment mechanism, and

- the principal source of finance to at least a large part of the economy.

As they assume the lubrication role in the economy, banks assume several risks, amongst others, market risk, credit risk, operational risk and legal risk (Morgan \& Andersen, 1997). Venkat (2000) agrees with Morgan and Andersen (1997) classification of banking risk; however; Venkat (2000) replaced the legal risk with insurance risk. For Kupper (2000), banking risks can simply be classified into the following three main types, namely: credit risk, market risk and operational risk.

In a similar manner to Kupper (2000), Rose (2002) and Ragvahan (2003) indicate that bankers are concerned with six (6) types of risk, namely: credit risk, liquidity risk, market risk, interest rate risk, earnings risk and solvency risk. In 2006, Moreno (2006) conducted a survey to determine the leading risks facing banks in emerging markets. In line with other researchers on the risks facing banks, Moreno's (2006) findings revealed that banks in emerging markets were exposed to credit risk, market risk and liquidity risk.

In 2010, PricewaterhouseCoopers (2010) released the findings of their 'Banking Banana Skins' survey. 
According to the results of the survey, the 2008 turmoil in global financial markets completely transformed the banking risk landscape. This is because risks which did not feature in the previous survey (i.e., the 2008 survey) became prominent in the later survey, i.e., political risk. Accordingly, the top four banking risks were observed as political risk, credit risk, too much regulation, and macro-economic trends.

Of the risks discussed above, several researchers have posited that credit risk remains the main risk in the banking sector due to the nature of banking. This paper investigates the nature of credit risk information disclosed in the risk and capital reports of South African banks. Based on the asset size, there are five dominant banks in the South African landscape. These banks are the ABSA Bank Limited, the First Rand Bank Limited, the Investec Bank Limited, the Nedbank Limited, and the Standard Bank of South Africa Limited. In terms of the asset size, these banks hold $89.2 \%$ (this percentage was $90.6 \%$ when it was measured in December 2014) of the total banking assets (SARB Banking Supervision Annual Report, 2015).

\section{A review of existing literature on credit risk}

From the brief discussion in the introduction, it became clear that market risk, credit risk and operational risk can be accepted as risks prevalent to banks. To provide a perspective on the accepted banking risks, the following description on each risk is provided:

- Credit risk refers to a potential of financial loss resulting from the failure of customers to honour fully the terms of a loan or contract. Accordingly, this definition is now expanded to include the risk of loss in portfolio value as a result of migration from a higher risk grade to a lower one.

- Market risk refers to a risk to earnings arising from changes in interest rates or exchange rates, or from fluctuations in bond, equity or commodity prices. Accordingly, banks are subject to market risk in both the management of their balance sheets and in their trading operations.

- Operational risk refers to the potential financial loss as a result of a breakdown in day-to-day operational processes. Accordingly, operational risk can arise from failure to comply with policies, laws and regulations, from fraud or forgery, or from a breakdown in the availability or integrity of services, systems or information (Kupper, 2000).

Having highlighted the risks prevalent to banks, Sinkey (1992) asserted that credit risk has commonly been identified as the leading risk due to its influence on bank performance. The influence of credit risk on banks is revealed by the role banks take part in which
Okeahalam (1998) views it as depository intermediaries that borrow funds from lenders and lend them to borrowers.

Sinkey's (1992) assertion that credit risk has a major influence on the banks performance was confirmed when Australian banks recorded the aggregate loan losses of around $\$ 25$ billion in the period between 1980s and early 1990s. The recorded losses prompted the Reserve Bank of Australia to follow Sinkey (1992) and declare credit risk as the biggest risk facing banks (Reserve Bank of Australia, 1997).

The Basel Committee on Banking Supervision also confirmed credit risk as the main risk in the banking system. In their publication, the committee argued that exposure to credit risk continues to be the leading source of problems in banks world-wide (Bank of International Settlement, 2000). Almost a decade after Sinkey (1992), the influence of credit risk on banks resurfaced this time on the Comptroller's Handbook (2001) where credit risk is viewed as the primary financial risk in the banking system. It is observed that the view on the influence of credit risk in banks expressed on the Comptroller's Handbook (2001) is consistent to the earlier views (i.e., Sinkey, 1992).

According to Safakli (2007), credit risk is an important risk in the banking sector due to the fact that it plays the major role, as the largest asset item is loans in the bank's balance sheet, which accordingly account for half to almost three-quarters of the total value of all other assets in the bank's balance sheet. In the recent years, credit risk continues to be the most influential risk in the banking system. The recent examples include Huang and Oosterlee (2009) proposition that credit risk is the largest source of risk facing banking institutions. Further on, the 'Banking Banana Skins' survey by PwC (2010) also highlighted credit risk as one of the highest risks facing banks.

Examined literature appear to support the view that credit risk remains an influential risk in the banking system due to the role of banks. With regards to the definition of what credit risk is, Santomero (1997) posits that credit risk may arise from either the inability or the unwillingness of the borrower to perform in the pre-committed contracted manner. The International Organization of Securities Commissions (IOSCO) (1998) supports this definition of credit risk where they explained that credit risk involved the likelihood that one of the parties to the contract will not honour its obligations as they become due.

According to Rose (2002), the probability that some of the bank's assets, particularly loans, which, according to Safakli (2007), are the largest asset item in the bank's balance sheet, will decline in value and perhaps become worthless overtime is known as credit risk. Another definition in line with other 
credit risk definitions was proposed by the Bank of International Settlements in 2004. Accordingly, credit risk is defined as the potential that a bank borrower or counterparty will fail to meet its obligations in accordance with agreed terms (Bank of International Settlements, 2004).

Casu et al. (2006) view credit risk as the risk that is associated with the traditional lending activity of banks and they simply described it as a risk of a loan not being repaid partly or in full. They, however, also acknowledge that credit risk can also derive from holding debt and other securities.

From the definitions of credit risk above, it is apparent that credit risk comprises of a risk of loss resulting from counterparty default on various sources such as loans, swaps, options, and during settlement. The ABSA Group Interim Risk and Capital Report (2009) support the view that there are different sources of risk facing financial institution. This is apparent in their definition where credit risk is stated as a risk that includes the risk of losses arising from mark-to-market requirements due to changes in credit spreads.

\section{Objectives, scope and delineation}

As indicated above, amongst several risks that banks assume, several researchers have argued that because of the core nature of the banking business, which is transforming deposits into investment through lending, the risk that should be given more attention is credit risk. Accordingly, failure to manage credit risk could lead to defaults, capital losses and generally a loss of confidence to a bank and the banking system in general and run on banks. Several researchers have argued that any major bank failure will have a negative impact on the overall financial sector and the overall economy as depositors lose their deposit and the stock-holders and debt-holders of the bank lose their wealth (King \& Levine, 1993; Ali, 2007; Kupiec \& Ramirez, 2009 and Minamihashi, 2009).

Since credit risk could have catastrophic implications, it is argued that central banks, investors and depositors would, then, be interested in the manner in which credit risk is managed by banks. Central banks, due to their power that involves the supervision of banks could obtain information through their visits and oversight activities. However, stakeholders such as investors and depositors would rely on the information made available by banks for informed decision (i.e., publicly available information). It is on this regard that this study explores the nature of credit risk information reported in the top South African bank's risk and capital reports.

As of 2015, there were 17 banks registered with the South African Reserve Bank (SARB). According to the SARB Banking Supervision Annual Report (2015), the banking sector in South Africa continues to be dominated by five largest banks. Collectively and as at 31 December 2015, these dominant banks held $89.2 \%$ (this percentage was $90.6 \%$ when it was measured in December 2014) of the total banking assets.

The total asset structure in the South African banking sector is given in the table below:

Table 1. Total asset structure in the South African banking sector

\begin{tabular}{|l|c|c|}
\hline \multicolumn{1}{|c|}{ Detail } & $\begin{array}{c}\text { \% of total banking asset De- } \\
\text { cember 2015 }\end{array}$ & \% of total banking asset 2014 \\
\hline Top five banks & 89 & 91 \\
\hline Local branches of international banks & 7 & 6 \\
\hline Other banks & 4 & 3 \\
\hline Total & 100 & 100 \\
\hline
\end{tabular}

Source: South African Reserve Bank Banking Supervision Report, 2015.

Based on the discussions above, the assessment of credit risk information disclosed by South African banks was limited to the top-5 banks. This is due to the fact that they dominate almost the entire sector in terms of the banking assets size.

\section{Methodology}

For the purpose of this study, which is the exploration of the nature of information disclosed as credit risk information in the risk and capital reports of the top-5 South African banks, the empirical method known as content analysis was used as a coding method for the selected reports. Krippendorff (1980) outlined three (3) factors that support the suitability of content analysis that can be used for the purpose of coding information in reports, namely: stability, reproducibility and accuracy. Accordingly, these concepts are discussed below:

- Stability refers to the ability of a researcher to code data the same way over time. Assessing stability of the content analysis methodology involves a testretest procedure.

- Accuracy refers to the reliability of the coded information.

- Reproducibility refers to the extent to which coding produces the same results when the text is coded once more (for the second time) or by the other researchers. 
The suitability of content analysis in coding reports is further highlighted by Hsieh and Shanon (2005) where they indicate that the content analysis methodology is not a single focused methodology, as it has three dimensions, namely, conventional, directed and summative.

It is important to note that recent literature still support the use of the content analysis methodology as an acceptable research method for analyzing reports, because the technique is particularly useful for extracting information that is not explicitly presented in a quantified and structured format, but is implicit in the text (Abeysekera, 2007; Boesso \& Kumar, 2007; Brennan \& Solomon, 2008; Barac \& Moloi, 2010; Moloi, 2016).

The content analysis was preferred as a methodology to extract the information in the risk and capital reports of the top-5 South African banks, firstly, because it has been widely used by various researchers in coding reports. Secondly, the content analysis methodology can be used in both qualitative and quantitative data. Thirdly, the content analysis methodology is content sensitive. For the content analysis to achieve its objective of extracting the information which could contain credit risk, the appropriate information need to be coded from the risk and capital reports of selected banks.

To extract the relevant information from the risk and capital reports, the Credit Risk Disclosure Measurement Tool (CRDMT) was created. The CRDMT assessed the risk and capital reports on six main areas, namely:

- bank's own description of credit risk (i.e., as it applies to the banks operations),

- bank's strategy of reducing credit risk exposure (i.e., objectives of credit management),

- bank's approach to credit modelling or the internal rating system,

- bank's approach and the manner in which it assesses its exposure to credit risk,

- bank's credit risk mitigation strategies employed (i.e., collateral and other credit enhancements), and;
- bank's approach to the valuation of pledged collateral and other credit enhancements.

The mathematical equation for the perceived informative risk and capital management report, when it comes to the credit risk information contained can, therefore, be expressed in the following manner:

$I R C M R=\alpha_{o+} \alpha_{1} B O D C R+\alpha_{2} B S R C R+\alpha_{3} B A C M S+$

$+\alpha_{4} B A E C R+\alpha_{5} B C R M S+\alpha_{6} B A V P C+A_{i}$,

where

- IRCMR is the informative risk and capital management report.

- BODCR represent the information relating to the bank's own description of credit risk.

- BSRCR represent the information relating to the bank's strategy of reducing credit risk exposure.

- BACMS represent the information relating to the bank's approach to credit modelling or the internal rating system.

- BAECR represent the information relating to the bank's approach and the manner in which it assesses its exposure to credit risk.

- BCRMS represent the information relating to the bank's credit risk mitigation strategies employed

- BAVPC represent the information relating to the bank's approach to the valuation of pledged collateral and other credit enhancements.

- A represent any additional useful information that the bank would disclose as part of this section.

\section{Analysis and interpretation of findings}

The results demonstrated below present the aggregated research findings obtained based on the analysis performed on the top-5 bank's risk and capital management reports for the 2014/15 financial year. These reports are publicly available and they were downloaded directly from the selected banks websites. The disclosed credit risk information on these reports was directly assessed against the constructed guidelines for data analysis and extraction tool (see Appendix A).

Table 2. Consolidated results

\begin{tabular}{|c|l|c|c|c|c|c|}
\hline Code & \multicolumn{1}{|c|}{ Description } & Full disclosure & $\%$ & $\begin{array}{c}\text { Non-disclosure } \\
\text { Partly disclo- } \\
\text { sure }\end{array}$ & \% & - \\
\hline BODCR & $\begin{array}{l}\text { Bank's own description of credit risk (i.e., as it } \\
\text { applies to the banks operations). } n=6\end{array}$ & 5 & 100 & - & - \\
\hline BSRCR & $\begin{array}{l}\text { Bank's strategy of reducing credit risk exposure } \\
\text { (i.e., objectives of credit management). } n=6\end{array}$ & 2 & 40 & & -20 \\
\hline BACMS & $\begin{array}{l}\text { Bank's approach to credit modelling or the } \\
\text { internal rating system. } n=6\end{array}$ & 4 & 80 & - & - \\
\hline BAECR & $\begin{array}{l}\text { Bank's approach and the manner in which it } \\
\text { assesses its exposure to credit risk. } n=6\end{array}$ & 4 & 80 & - & -20 \\
\hline
\end{tabular}


Table 2 (cont.). Consolidated results

\begin{tabular}{|c|l|c|c|c|c|c|c|}
\hline Code & \multicolumn{1}{|c|}{ Description } & Full disclosure & $\%$ & Non-disclosure & $\%$ & $\begin{array}{c}\text { Partly disclo- } \\
\text { sure }\end{array}$ & $\%$ \\
\hline BCRMS & $\begin{array}{l}\text { Bank's credit risk mitigation strategies em- } \\
\text { ployed (i.e., collateral and other credit en- } \\
\text { hancements). } n=6\end{array}$ & 3 & 60 & 2 & 40 & - & - \\
\hline BAVPC & $\begin{array}{l}\text { Bank's approach to the valuation of pledged } \\
\text { collateral and other credit enhancements. } n=6\end{array}$ & 2 & 40 & 2 & 40 & 1 & 20 \\
\hline
\end{tabular}

Note: $n=$ number of risk and capital reports assessed.

This paper argues that for the risk and capital management report to be deemed useful, particularly when it comes to the credit risk information disclosed, it must as a minimum contain the information described in the Credit Risk Disclosure Measurement Tool (CRDMT) as the six main areas. These main areas are bank's own description of credit risk (i.e., as it applies to the banks operations), bank's strategy of reducing credit risk exposure (i.e., objectives of credit management), bank's approach to credit modelling or the internal rating system, bank's approach and the manner in which they assess their exposure to credit risk, bank's credit risk mitigation strategies employed (i.e., collateral and other credit enhancements), and bank's approach to the valuation of pledged collateral and other credit enhancements.

Obtained results in Table 2 above demonstrate that in general, the top-5 South African banks are fairly in line with the main six credit risk areas that should be contained in the risk and capital management report, as proposed by the CRMDT. There are, however, pockets that could be improved to enhance the risk and capital management reports, particularly the credit risk information made available to public.

The areas which require improvement include:

- Bank's credit risk mitigation strategies employed (40\% of assessed risk and capital reports did not have this information) and bank's strategy of reducing credit risk exposure (40\% of assessed risk and capital reports did not have this information). In this regard, investors and depositors would require comfort that those charged with managing banks have put something together and that this is being implemented to reduce exposure.

- Bank's approach to the valuation of pledged collateral other credit enhancements $(40 \%$ of assessed risk and capital reports did not have this information). Investors and depositors would require comfort that those charged with managing banks have evaluated and are satisfied with the quality of collateral and other credit enhancement instrument to reduce exposure.

\section{Summary, conclusion and recommendations}

Following the review of literature which suggested that several researchers were in agreement that any major bank failure will have a negative impact on the overall financial sector and the overall economy, as depositors lose their deposit and the stock holders and debtholders of the bank lose their wealth. And that credit risk could have catastrophic implications, this study argued that central banks, investors and depositors would, then, be interested in the manner in which credit risk is managed by banks. As such, this study explored the nature of credit risk information disclosed in the risk and capital management reports of the top-5 South African Banks.

To achieve its main goal, this paper created the Credit Risk Disclosure Measurement Tool (CRDMT) so that it could assess risk and capital management reports on six main areas, namely: bank's own description of credit risk (i.e., gas it applies to the bank's operations), bank's strategy of reducing credit risk exposure (i.e., objectives of credit management), bank's approach to credit modelling or the internal rating system, bank's approach and the manner in which they assess their exposure to credit risk, bank's credit risk mitigation strategies employed (i.e., collateral and other credit enhancements), and bank's approach to the valuation of pledged collateral and other credit enhancements.

The results obtained through the content analysis methodology and utilizing the CRMDT demonstrated that in general, the top-5 South African banks are fairly in line with the main six credit risk areas that should be contained in the risk and capital management report, as proposed by the CRMDT. There are, however, pockets that could be improved to enhance the risk and capital management reports, particularly the credit risk information made available to public. The areas which require improvement include the information relating to bank's credit risk mitigation strategies employed (40\% of assessed risk and capital reports did not have this information) and bank's strategy of reducing credit risk exposure (40\% of assessed risk and capital reports did not have this information). In this regard, it was suggested that this information is important, as investors and depositors would require comfort that those charged with managing banks have put something together and that this is being implemented to reduce exposure.

Another area that requires improvement is the information relating to banks approach to the valuation of pledged collateral other credit enhancements ( $40 \%$ of assessed risk and capital reports did not have this 
information). This paper suggested that this information was important, as investors and depositors would require comfort that those charged with man- aging banks have evaluated and are satisfied with the quality of collateral and other credit enhancement instrument to reduce exposure.

\section{References}

1. Abeysekera, I. (2007). Intellectual capital reporting between a developing and developed nation, Journal of Intellectual Capital, 8 (2), pp. 329-345.

2. ABSA. (2009). Interim risk and capital management report for the six months ended 30 June 2009. ABSA Group Limited.

3. Ali, S.S. (2007). Financial distress and bank failure: lessons from closure of Ihlas Finans in Turleading, Islamic Economic Studies, 14 (1\&2), pp. 1-52.

4. Allen, F. \& Carletti, E. (2008). The role of banks in a financial system. Oxford Handbook of Banking. Edited by Allen Berger, Phil Molyneux and John Wilson.

5. Bangura, S.A.F. (2005). Statistical Information and the Banking Sector. United Nations Economic Commission for Africa, Ethiopia.

6. Bank of International Settlement. (2000). Principles for management of credit risk. Switzerland, Basel: Basel Committee on Banking Supervision, BIS.

7. Barac, K. \& Moloi, T. (2010). Assessment of corporate governance reporting in the annual reports of South African listed companies, The South African Journal of Accountability and Auditing Research, 10 (1), pp. 19-28.

8. Boesso, G. \& Kumar, K. (2007). Drivers of corporate voluntarily disclosure: A framework and empirical evidence from Italy and the United States, Accounting, Auditing and Accountability Journal, 20 (2), pp. 269-296.

9. Boot, A.W.A. \& Marinc, M. (2008). The evolving landscape of banking, Industrial and Corporate Change, 17 (6), pp. 1173-1203.

10. Brennan, N. \& Solomon, J. (2008). Corporate governance, accountability and mechanisms of accountability: an overview, Accounting, Auditing \& Accountability, 21 (7), pp. 885-906.

11. Casu, B.; Girardone, C. \& Molyneux, P. (2006). Introduction to Banking. Pearson Education Ltd: England.

12. Comptroller's Handbook. (2001). Rating Credit Risk. Comptroller of the Currency Administrator of National Banks.

13. Diamond, D.W. \& Dybvig, P. (1983). Bank runs, deposit insurance, and liquidity, Journal of Political Economy, 91, pp. 401-419.

14. Gurley, J.G. \& Shaw, E.S. (1960). Money in a Theory of Finance. Washington DC, Brookings Institution.

15. Hsieh, F.H. \& Shanon, S.E. (2005). Three approaches to qualitative content analysis, Qualitative Health Research, 15 (9), pp. 1277-1288.

16. Huang, X. \& Oosterlee, C.W. (2009). Improving Banks' Credit Risk Management. European Research Consortium for Informatics and Mathematics. Sophia Antipolis Cedex, France.

17. International Organisation of Securities Commission. (1998). Risk Management and Control Guidance for Securities Firms and their Supervisors. Consultative Document. IOSCO.

18. Kaufman, G.G. (1988). Bank runs: causes, benefits and costs, Cato Journal, 7 (3), pp. 559-594.

19. King, R. \& Levine, R. (1993). Finance and Growth: Schumpeter Might Be Right, Quarterly Journal of Economics, 108, pp. 717-37.

20. Kupiec, P.H. \& Ramirez, C.D. (2009). Bank Failures and the Cost of Systemic Risk: Evidence from 1900-1930. Federal Deposit Insurance Corporation, Centre for Financial Research.

21. Kupper, E.F. (2000). Risk management in banking. Australian Prudential Regulation Authority. Risk and Capital Management Conference Proceedings, Sydney.

22. Lewis, M.K. (1992). Banking as Insurance. In E.P.M. Gardener (ed.). The Future of Financial Systems and Services. London, Macmillan.

23. Liu, V. (2004). Environmental Considerations and Business Operations of Commercial Banks in China - A case Study of the Project Loan Appraisal Policy of ICBC. Lund, Sweden, IIIEE.

24. Minamihashi, N. (2009). Credit Crunch Caused by Bank Failures and Self-Selection Behaviour in Lending Markets. Boston University: United States.

25. Moloi, S.T.M. (2014). Leading Credit Risk Indicators in the Top South African Banks. Doctoral Thesis, Universidad Central de Nicaragua: Managua.

26. Moloi, T. (2016). Key mechanisms of risk management in South Africa's National Government Departments: the Public Sector Risk Management Framework and the King III benchmark, International Public Administration Review, 14 (2-3), pp. 37-52.

27. Morgan, J.P. \& Andersen, A. (1997). Guide to Corporate Risk Management. Risk Publications: London.

28. Moreno, R. (2006). The changing nature of risks facing banks. BIS Paper No. 28. Bank of International Settlements.

29. PriceWaterHouseCoopers. (2010). Banking Banana Skins 2010: After the quake. United Kingdom: Heron, Dawson \& Sawyer.

30. Ragvahan, R.S. (2003). Risk Management in Banks. Indian Institute of Chartered Accountants: India.

31. Reserve Bank of Australia. (1997). Credit Risk in Banking. Retrieved February 09, 2013, from http://www.rba.gov.au/publications/bulletin/1997/nov/pdf/bu-1197-3.pdf. 
32. Rose, P. (2002). Commercial Bank Management. 5th edition. McGraw-Hill/Irwin: USA.

33. South African Reserve Bank (SARB). (2015). Banking Supervision Annual Report. South African Reserve Bank: Pretoria.

34. Safakli, O.V. (2007). Credit risk assessment for the banking sector in Cyprus, Banks and Bank Systems, 2 (1), pp. 21-31.

35. Santomero, A.M. (1997). Commercial Bank Risk Management: an Analysis of the Process. Wharton Financial Institutions Center Conference on Risk Management in Banking, October 13-15, 1996. University of Pennsylvania.

36. Sinkey, J.F. (1992). Commercial Bank Financial Management in the Financial Services industry. $4^{\text {th }}$ edition. MacMillan Publishing Company: New York.

37. Venkat, S. (2000). Implementing a firm-wide risk management process. Professional Handbook of Financial Risk Management. Edited by Lore, M and Borodovsky, L. Oxford: Butterworth, Heinemann.

38. Wilson, J.O.S., Casu, B., Girardone, C. \& Molyneux, P. (2010). Emerging themes in banking: Recent literature and directions for future research, The British Accounting Review, 42, pp. 153-169.

Appendix A. Guiding principles for data extraction and analysis: the credit risk disclosure measurement

\begin{tabular}{|c|c|c|c|}
\hline & Full disclosure of relevant information & Non-disclosure of relevant information & Partly disclosure of relevant information \\
\hline $\begin{array}{l}\text { Guiding disclosure } \\
\text { principles }\end{array}$ & $\begin{array}{l}\text { The particular risk and capital report of } \\
\text { the bank being measured has fully } \\
\text { disclosed the information relating to the } \\
\text { category being measured. The informa- } \\
\text { tion contained in that category is } \\
\text { deemed sufficient as a description of the } \\
\text { category concerned and would result in } \\
\text { an informed decision. }\end{array}$ & $\begin{array}{l}\text { The particular risk and capital manage- } \\
\text { ment report of the bank being measured } \\
\text { has not disclosed the information relating } \\
\text { to the category being measured. }\end{array}$ & $\begin{array}{l}\text { The particular risk and capital report of the } \\
\text { bank being measured has partly disclosed } \\
\text { the information relating to the category being } \\
\text { measured. The information contained in that } \\
\text { category is deemed insufficient as a descrip- } \\
\text { tion of the category concerned and would not } \\
\text { necessarily result in an informed decision. }\end{array}$ \\
\hline
\end{tabular}

